\title{
Effect of Depression on Hypertension among Turkish Individuals Aged 30 and over Years
}

\author{
Alaettin Unsal1, Mustafa Tozun², Unal Ayranci ${ }^{*}$ \\ ${ }^{1}$ Department of Public Health, Medical Faculty, Eskisehir Osmangazi University, Eskisehir, Turkey \\ ${ }^{2}$ Department of Public Health, Medical Faculty, Izmir Katip Celebi University, Izmir, Turkey \\ ${ }^{3}$ Medico Social Center, Eskisehir Osmangazi University, Eskisehir, Turkey \\ Email: alaettinunsal@yahoo.com, mustafatozun1@yahoo.com, ${ }^{*}$ ayranciunal@yahoo.com
}

Received 8 May 2014; revised 20 June 2014; accepted 6 July 2014

Copyright (C) 2014 by authors and Scientific Research Publishing Inc.

This work is licensed under the Creative Commons Attribution International License (CC BY). http://creativecommons.org/licenses/by/4.0/

(c) (i) Open Access

\begin{abstract}
Background: It is well known that depression is effective upon the occurrence of hypertension. The aim was to determine the prevalence of depression in the population aged 30 years old and over, and its impact on hypertension. Methods: This study is a cross-sectional study conducted on people aged 30 years and over between Sep., 1st and Oct., 30th 2009 in a region of western Turkey, Eskisehir. The questionnaire included the information about the subjects' sociodemographic characteristics and the Beck Depression Inventory (BDI) used to determine those who were at the risk of depression. The data were analyzed using Student's $t$ test, Chi-square test and Logistic regression analysis. A value of $p<0.05$ was considered statistically significant. Results: According to the Logistic analysis, older age $(O R=16.050)$, adding extra salt to meals $(O R=2.079)$, obesity $(O R$ $=2.170)$ and family history of hypertension $(O R=2.139)$ were the important risk factors for hypertension ( $p<0.05$ for each one). It was determined that there was a positive connection between the scores received from the BDI and systolic and diastolic BP values $\left[\left(r_{s}=0.151 ; p<0.001\right)\right.$ and $\left.\left(r_{s}=0.146 ; p<0.001\right)\right]$, respectively. Conclusion: According to the above results, we may conclude that depression is effective upon the occurrence of hypertension.
\end{abstract}

\section{Keywords}

Hypertension, Depression, Turkey, Adults, Beck Depression Inventory, Blood Pressure

\section{Background}

Many studies have indicated that risk factors for hypertension include older age, female gender, smoking, alco-

\footnotetext{
${ }^{*}$ Corresponding author.
} 
hol consumption, unemployment, low education level, stress, positive family history, insufficient physical activities, bad dietary habits, obesity, presence of high systolic and diastolic blood pressure (BP), elevated total LDL cholesterol, and diabetes mellitus (DM) [1].

Various studies have been conducted involving adult hypertensives from Mexico to Egypt, and it has been proposed that the prevalence of hypertension among adults ranges from $5.2 \%$ to $70.7 \%$ [2] [3]. Many studies conducted in Turkey and other countries have shown that women have a significantly higher prevalence than men (34.1\% and $15.6 \%$, respectively) [4] [5]. In Turkey, it is known that one of every 6 persons in the age group of 30 years and over, and one in every 5 persons in the age group of 40 years and over had a blood pressure above the normal range, and that the prevalence of hypertension in adults was between $29 \%$ - 49\% [6].

Although traditional information is that depression increases together with the age, there are also studies proving that it increases between 30 and 40 years old people and declines after 45 [7]. In many studies in Turkey, the age above 40 is described as a risk group in depressive disorders [8].

Symptoms of depression include loss of energy, self-loathing, reckless behavior, concentration problems, feelings of helplessness and hopelessness, loss of interest in daily activities, appetite and sleep changes, irritability, aches and pains. Depression has been proposed as a likely risk factor for hypertension and coronary heart disease (CHD). It has recently been found to predict recurrence of and mortality due to MI in a series of studies [9], and hypertension incidence in a prospective population-based study [10]. The relation between depression and hypertension is biologically plausible given the increased adrenergic activity in depression [11] that may have a pressor effect on the cardiovascular system.

The present cross-sectional study sought to address the impact of depression on hypertension in the population aged 30 years and over.

\section{Methods}

This study is a cross-sectional study conducted on people aged 30 years and over between Sep., 1st and Oct., 30th 2009 in a village in western Turkey, Kaymaz.

\subsection{Participants}

According to the records of the Sivrihisar Community Health Center for the year 2009, the number of those living in the village was 1.005 , most of them $(n=448,44.6 \%)$ were women, and 457 were men $(55.4 \%) .61 .9 \%$ of the men $(n=283)$ and $82.1 \%$ of the women $(n=368)$ were over the age of 30 (in total 565/961 $=58.8 \%)$. Participation was voluntary and anonymous, and the Director of the Institution approved this study. The including criteria was that subjects who had both depression and hypertension. Of total 651 individuals, 56 were excluded from the survey due to: unwillingness to participate in the research $(n=31)$, and not being at home at the time of the study $(n=25)$. The remaining $86.8 \%$ women $(n=565 / 651)$ who agreed to participate in the study, constituted the study group.

\subsection{Questionnaires}

The questionnaire consisted of two parts. One included information about the subjects' sociodemographic characteristics and health status such as sex, age, education level, marital status, job, height, weight, family history of hypertension, status of BP measurement, history of hypertension, use of antihypertensive agents, diagnosis of nephropathy, diabetes mellitus or another chronic disease, alcohol consumption, smoking cigarette, physical activity, and some other factors related to hypertension and depression.

The other one included the Beck Depression Inventory (BDI) used to determine those who were at the risk of depression, which consisted of 21 items. Subjects were asked to choose 1 sentence from a group of 3 that best described their feelings within the past 2 weeks. High scores from the items indicated a higher incidence of depressive symptoms. The BDI, used as a screening test in this survey, was developed by Beck et al. (1961) [12] and later modified by Hisli (1999) [13] to suit the Turkish culture and norms. The inventory has been widely used in various studies in Turkey, and it has been accepted that the Turkish version of the scale has sufficient reliability and criterion-related validity. It was a self-administrated questionnaire administered as a face-to-face interview. The answer for each item was evaluated as 0,1 , and 2 points. The lowest point was accepted as " 0 " and the highest point “63", with a cutoff point of 17 . If a student had $\geq 17$ points, the student was accepted as at 
risk of depression [13]. In addition to the questionnaire, the subjects' BP, height and weight were measured at the end of each interview.

\subsection{Research Procedures}

BP measured was made according to the criteria reported by the Joint National Committee on Prevention, Detection, Evaluation, and Treatment of High Blood Pressure-7 (JNC 7) criteria [14]. BP was measured with aneroid sphygmomanometers after the participant had been seated and rested for 5 minutes. Two measurements were taken at an interval of 2 minutes between readings, and the average of the 2 recordings was accepted as the subject's BP. The reading was accepted as hypertensive if SBP was $\geq 140 \mathrm{mmHg}$ and/or DBP $\geq 90 \mathrm{mmHg}$ and/or if the subject was taking antihypertensive agents, or if BP of the subject with DM was $\geq 130 / 80 \mathrm{mmHg}$. By the JNC 7, "normal” BP was defined as SBP $<120 \mathrm{mmHg}$ and DBP $<80 \mathrm{mmHg}$.

Height measure was taken with measuring tape, and weight measure with a home type of Weight Bridge. Subjects were considered as obese if they had a body mass index (BMI) of $30 \mathrm{~kg} / \mathrm{m}^{2}$ or more.

Unemployed, housewives and retirees were considered to be not working. Mother, father or sibling history of hypertension in any of the individuals was accepted as positive family history of hypertension. A smoker was defined as having smoked at least one cigarette per day, and alcohol consumer as having reported a weekly alcohol intake of more than $30 \mathrm{ml}$ ethanol. Doing regular physical activity was evaluated as going for a walk more than 30 minutes and doing physical activity more than two times in a week. Excessive salt intake was indicated if the individual reported the use of supplementary salt in every meal constituting more than $6 \mathrm{~g}$ salt daily at meals. We divided the types of oil into two classes: vegetable and animal. Chronic diseases were identified as DM, chronic renal disease (CRD), Chronic Heart Disease (CHD), and all the other chronic diseases with the exception of hypertension.

\subsection{Statistical Analysis}

Statistical analysis was made using Student's $t$ test, Chi-square test and Spearman Correlation Test. Significantly related variables were assessed in a model with Logistic regression (stepwise backward Wald regression). Goodness of fit was calculated with the Hosmer-Lemeshow $\mathrm{C}$ statistic. Results were given as numbers and percentages with a $95 \%$ confidence interval $(C I)$. A value of $\mathrm{p}<0.05$ was considered statistically significant.

\section{Results}

In this study, the data obtained from the 565 subjects were analyzed. Their mean age was $58.15 \pm 13.74$ (range 30 - 90) years. The study group consisted of 226 males (40.0\%) and 339 females (60.0\%). Most subjects were in the age group of 60 and over (48.0\%) and had an educational level of primary school (66.0\%). 430 (76.1\%) of those in the study group were married, and $416(73.6 \%)$ were not working in any job.

A total of $24.1 \%(n=136)$ of the study group were smokers and $12.7 \%(n=72)$ alcohol consumers. The number of those doing regular physical activity was 243 (43.0\%), 273 (48.3\%) subjects were using supplementary salt, and 535 (94.7\%) for vegetable oil. More detailed characteristics of the study group are presented in Table 1.

The prevalence of obesity in the subjects was $36.5 \%$, with 206 subjects including 35 males (15.5\%) and 171 females $(50.4 \%)\left(x^{2}=71.521 ; \mathrm{p}=0.000\right)$. The proportion of those with a family history of hypertension was 51.7\% (292/565), (men 91, 40.3\%; women 201, 59.3\%).

$36.6 \%(207 / 565)$ of the subjects in the study groups reported that they had had at least one or more chronic diseases previously diagnosed. $46.2 \%(n=110)$ of those with hypertension and $29.7 \%$ of those without hypertension had at least one history of chronic disease $\left(x^{2}=16.262 ; p=0.000\right)$. The number of those who had a history of more than one chronic disease was 11 and the total number of chronic diseases was 121 . Of the subjects, $39.7 \%$ had DM $(n=48), 6.6 \%$ CHD $(n=8), 14.1 \%$ rheumatic disease $(n=17), 9.1 \%$ peptic ulcus $(n=11), 5.8 \%$ asthma ( $n=7)$ and $24.7 \%$ the other diseases $(n=30)$.

The average SBP of the subjects was $132.36 \pm 23.10 \mathrm{mmHg}$, with $129.40 \pm 21.71 \mathrm{mmHg}$ in men and 134.34 $\pm 23.80 \mathrm{mmHg}$ in women $(\mathrm{t}=2.500 ; \mathrm{p}=0.013)$; similarly, the average DBP of the subjects was $80.99 \pm 14.03$ $\mathrm{mmHg}$, with $78.54 \pm 13.36 \mathrm{mmHg}$ in men and $82.63 \pm 14.25 \mathrm{mmHg}$ in women $(\mathrm{t}=3.423 ; \mathrm{p}=0.001)$.

The subjects' prevalence of depression was found to be $21.4 \%$ (121/565) and the prevalence of hypertension 
Table 1. Some characteristics of the study group.

\begin{tabular}{|c|c|c|}
\hline Characteristics & $\begin{array}{c}\mathrm{n} \\
565\end{array}$ & $\begin{array}{c}(\%) \\
100.0\end{array}$ \\
\hline \multicolumn{3}{|l|}{ Sex } \\
\hline Male & 226 & 40.0 \\
\hline Female & 339 & 60.0 \\
\hline \multicolumn{3}{|l|}{ Age group (year) } \\
\hline $30-39$ & 66 & 11.7 \\
\hline $40-49$ & 74 & 13.1 \\
\hline $50-59$ & 154 & 27.2 \\
\hline$\geq 60$ & 271 & 48.0 \\
\hline \multicolumn{3}{|l|}{ Educational level } \\
\hline Secondary school and upper & 86 & 15.3 \\
\hline Primary school & 373 & 66.0 \\
\hline Illiterate & 106 & 18.7 \\
\hline \multicolumn{3}{|l|}{ Marital status } \\
\hline Married & 430 & 76.1 \\
\hline Unmarried & 135 & 23.9 \\
\hline \multicolumn{3}{|l|}{ Job status } \\
\hline No & 416 & 73.6 \\
\hline Yes & 149 & 26.4 \\
\hline \multicolumn{3}{|l|}{ Cigarette consumption } \\
\hline Yes & 136 & 24.1 \\
\hline No & 429 & 75.9 \\
\hline \multicolumn{3}{|l|}{ Alcohol consumption } \\
\hline Yes & 72 & 12.7 \\
\hline No & 493 & 87.3 \\
\hline \multicolumn{3}{|l|}{ Salt supplement } \\
\hline Yes & 292 & 51.7 \\
\hline No & 273 & 48.3 \\
\hline \multicolumn{3}{|l|}{ Oil type } \\
\hline Vegetable & 535 & 94.7 \\
\hline Animal & 30 & 5.3 \\
\hline \multicolumn{3}{|l|}{ Regularly physical activity } \\
\hline Yes & 243 & 43.0 \\
\hline No & 322 & 57.0 \\
\hline \multicolumn{3}{|l|}{ Obesity } \\
\hline Yes & 206 & 36.5 \\
\hline No & 359 & 63.5 \\
\hline \multicolumn{3}{|l|}{ Chronicle disease } \\
\hline Yes & 207 & 36.6 \\
\hline No & 358 & 63.4 \\
\hline \multicolumn{3}{|c|}{ Family history of hypertension } \\
\hline Yes & 292 & 51.7 \\
\hline No & 273 & 48.3 \\
\hline
\end{tabular}


was $42.1 \%(n=238 / 565) .48 .8 \%$ of those with depression $(n=59)$ and $40.3 \%$ of those without depression $(n=$ 179) had depressive diseases $\left(x^{2}=2.782 ; \mathrm{p}=0.095\right)$.

According to the Bivariate analysis results, significant differences was revealed between the existence of hypertension and the individuals' gender, age groups, educational levels, marital status, working status, smoking habit and alcohol consumption, adding extra salt to meals, the type of oil used in food, presence of regular physical activity, obesity, presence of any chronic disease by diagnosed by a physician, family history of hypertension and depression. Backward Stepwise Logistic Regression Analysis formed with the above variables, which showed significantly important findings, are given in Table 2. According to the model results, older age $(\mathrm{OR}=$ 16.050), adding extra salt to meals ( $\mathrm{OR}=2.079)$, obesity $(\mathrm{OR}=2.170)$ and family history of hypertension (OR $=2.139$ ) were the important risk factors for hypertension ( $\mathrm{p}<0.05$ for each one).

The average score that the subjects obtained from the BDI was $10.62 \pm 8.32 \mathrm{mmHg}$ (Range $=0-42$ ). The subjects' average systolic and diastolic BP values were $132.36 \pm 23.10 \mathrm{mmHg}$ (Range $=60-240$ ), $80.99 \pm$ $14.03 \mathrm{mmHg}$ (Range $=40$ - 160), respectively.

It was determined that there was a positive connection between the scores received from the BDI and systolic and diastolic BP values $\left[\left(\mathrm{r}_{\mathrm{s}}=0.151 ; \mathrm{p}=0.000\right)\right.$ and $\left.\left(\mathrm{r}_{\mathrm{s}}=0.146 ; \mathrm{p}=0.000\right)\right]$, respectively (Graph 1 and Graph 2).

\section{Discussion}

In this study, the prevalence of hypertension was $55.2 \%$, which was higher than that reported in various countries, showing that the prevalence among adults aged 30 years and over ranged from $19.8 \%$ to $54.5 \%$ [15]. One reason for this difference is that this study included the adults from only one small town although it was a community-based survey. In addition, the socioeconomic inequalities and different education of the people between countries or societies, a high obesity rate in the study area, different definitions of hypertension, a variety of screening methods, the diversity of study groups, and a large population of uneducated women may all contribute to the high prevalence. Another reason is that the subjects of our study group were older, 58.15 years on average.

This study revealed that the prevalence of hypertension increased significantly with the increase of age of individuals ( $\mathrm{p}<0.05$, for each one). This finding and other reports indicate that hypertension is related to older age [16]. Similar results have also been reported in studies conducted in the central regions of Turkey [6]. Furthermore, the TURKSAHA study aiming to investigate the use of antihypertensive agents in Primary Health Care (PHC) units for 16270 Turkish patients found that those aged 65 and over were significantly at risk from hypertension [17]. An explanation for increase in the prevalence of hypertension with increasing age could be that with age decrease of the amount of elastic fibers causes the elasticity of large arteries to reduce, causing an increase in vascular resistance and thus in BP [17].

Table 2. Significant independent variables for hypertension according to Logistic regression analysis (step 3).

\begin{tabular}{|cccc}
\hline Variables & $\mathbf{p}$ & $\mathbf{O R}^{\mathbf{a}}$ & $\mathbf{\% 9 5}_{\mathbf{~ C I}} \mathbf{I}^{\mathbf{b}}$ \\
\hline Constant & & & \\
\hline Age group (years) (reference: $\mathbf{3 0}-\mathbf{3 9})$ & & 2.166 & $0.878-5.342$ \\
$40-49$ & 0.093 & 7.674 & $3.345-17.608$ \\
$50-59$ & $\mathbf{0 . 0 0 0}$ & 16.050 & $6.913-37.266$ \\
$\geq 60$ & $\mathbf{0 . 0 0 0}$ & & $1.392-3.104$ \\
Salt intake (reference: no) & $\mathbf{0 . 0 0 0}$ & 2.079 & $1.377-3.421$ \\
Yes & & & $1.407-3.252$ \\
Obesite (reference: no) & $\mathbf{0 . 0 0 1}$ & 2.170 & \\
Yes & & 2.139 & \\
\hline
\end{tabular}

$\mathrm{OR}^{\mathrm{a}}$ : Odd's ratio, $\mathrm{CI}^{\mathrm{b}}$ : Confidence interval. (Hosmer and Lemeshow Test: $\mathrm{x}^{2}=3.146, \mathrm{df}=8 ; \mathrm{p}=0.925$ ). 


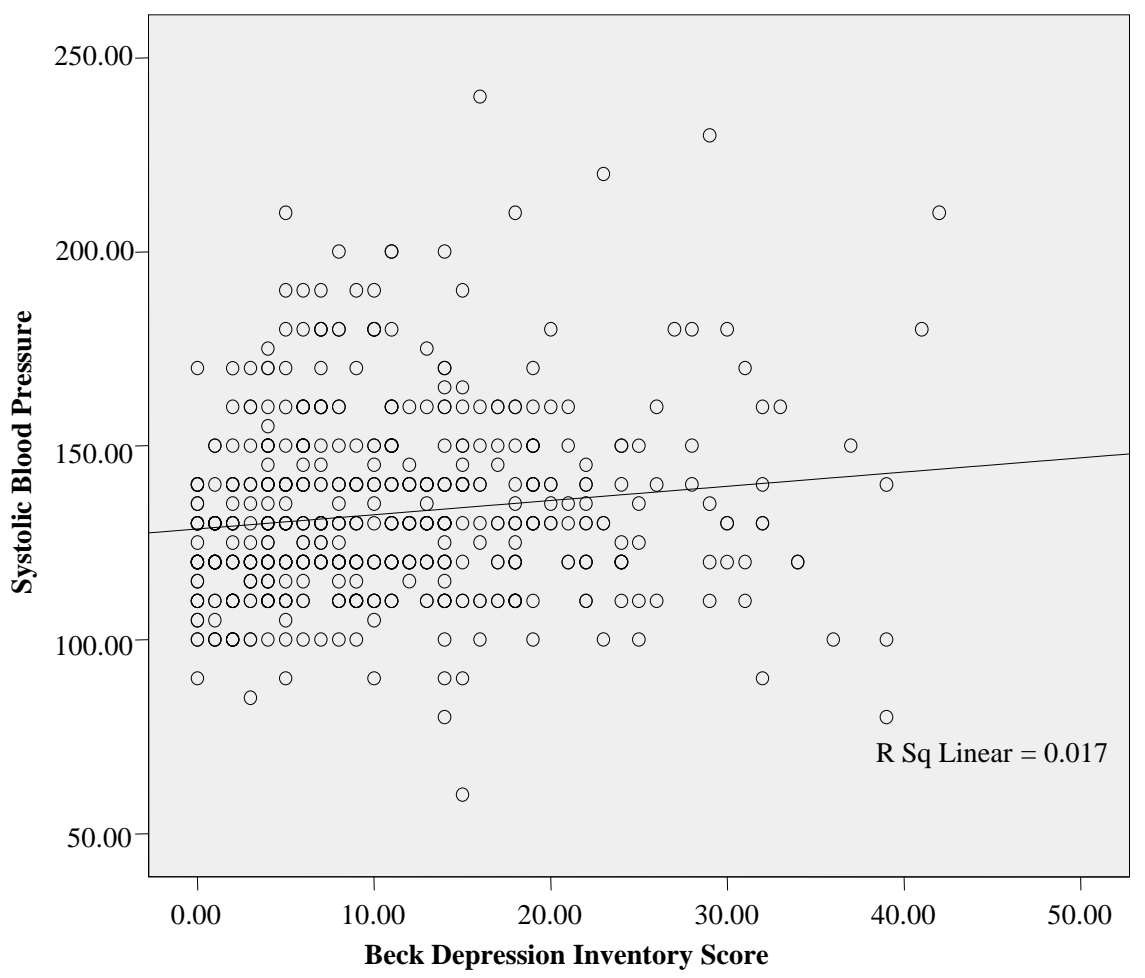

Graph 1. The scattering diagram of Beck Depression Inventory scores and systolic blood pressure values Beck Depression Inventory scores and systolic blood pressure values of.

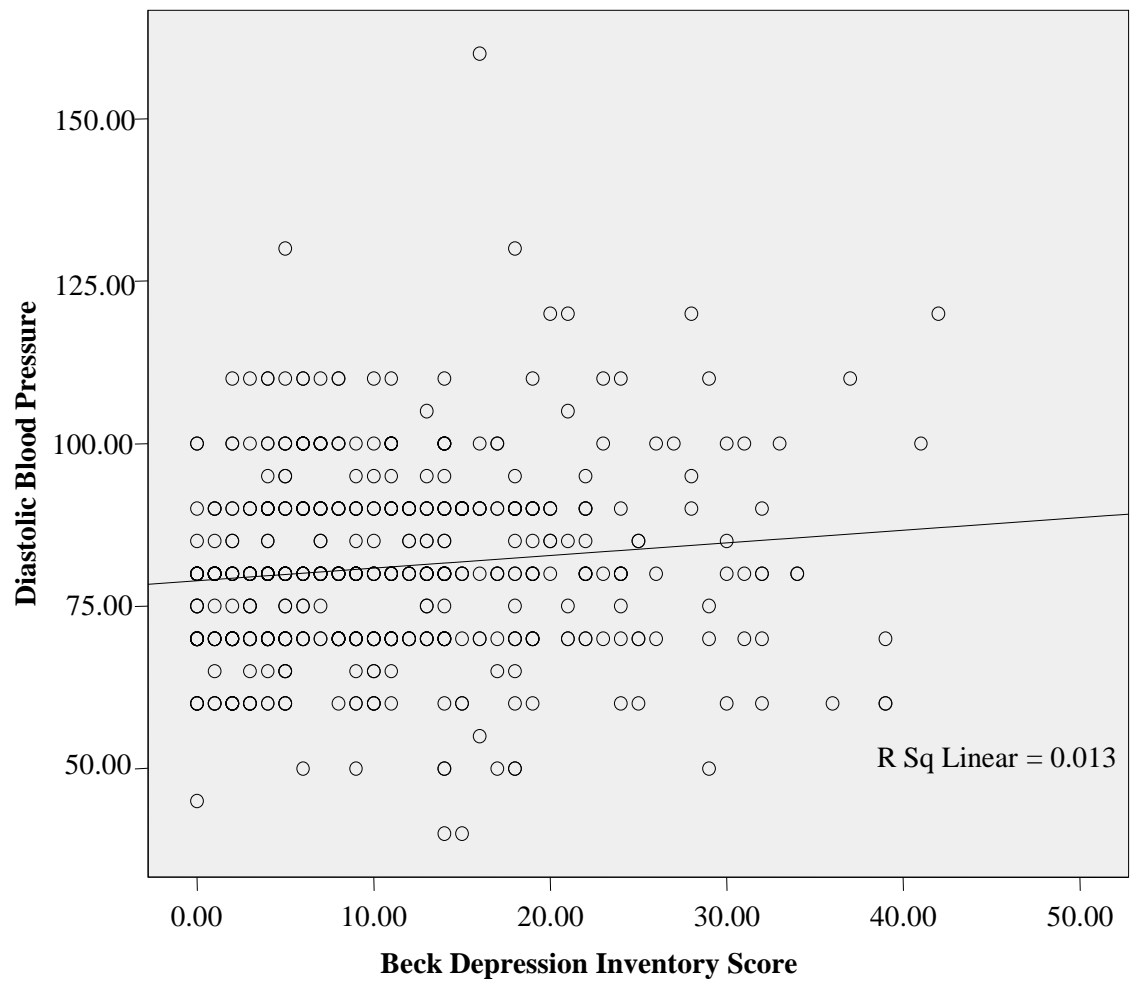

Graph 2. The scattering diagram of Beck Depression Inventory scores and diastolic blood pressure values. 
In this study, adding salt to meals was found to be a risk factor for hypertension ( $O R=2.079 ; \mathrm{p}<0.05$ ), consistent with many study findings [18]. A reason for these results could be as follows: Much salt intake in food causes the water retention and in result the heart flow to increase. In addition, much salt intake causes hypertension, changing renal function and vascular reactivity.

The growing prevalence of obesity is increasingly recognized as one of the most important risk factors for the development of hypertension. Based on population studies, risk estimates indicate that at least two-thirds of the prevalence of hypertension can be directly attributed to obesity [19]. An explanation for this could be that in those with obesity, the increasing body fat mass increases blood leptin hormone level. Leptin causes hypertension, accelerating proliferation in vascular smooth muscle cell, increasing vascular calcification, and stimulating angiogenesis. In our study, obesity was found to be a risk factor for hypertension (OR $=2.170 ; \mathrm{p}<0.05)$, consistent with the studies indicating that the prevalence of hypertension was higher in those with obesity than those without nonobesity [20].

Family history of hypertension was shown as one of the important risk factors for hypertension in this study $(\mathrm{OR}=2.139 ; \mathrm{p}<0.05)$. This finding is consistent with that reported elsewhere [2]. It has been reported that in studies associated with the genetic transition of hypertension the children of parents with high BP tend to be hypertensive [21]. A study by Oscar and Suzanne reported that if one of mother or father is hypertensive the risk of developing hypertension in their children increased two fold [3]. Obviously genetic factors may contribute to an estimated $30 \%$ of patients with essential hypertension. A large percentage of people with essential hypertension have genetic abnormalities of their peripheral arteries (arterioles) that supply blood to the body tissues. The abnormalities make the walls of the arteries stiff resulting in greater resistance to the blood flowing through them [22].

In the current study, it revealed a positive connection between SBP values $\left(r_{s}=0.151, p=0.000\right)$ and between DBP values $\left(r_{s}=0.146, p=0.000\right)$ with the scores received from the BDI, although there was no relationship between the presence of depression and hypertension, which is supported by many studies indicating that the prevalence of hypertension was higher in those depressive [23]. An explanation for this could be that the plasma norepinephrine level in the individuals with depression rises, and that norepinephrine increases BP, causing vasoconstriction.

In this study, hypertension was determined in more than half of the subjects and depression in about $1 / 5$. Older age, adding additional salt to meals, obesity and family history of hypertension were important risk factors for hypertension. In addition, there was a positive relationship between depression and systolic and diastolic BPs.

\section{Conclusion}

We conclude that these results suggest that depression is effective upon the occurrence of hypertension.

\section{Acknowledgements}

The authors wish to thank to the research subjects participating in the study for their valuable efforts and time.

\section{References}

[1] Sierra, C. and Sierra, A. (2008) Early Detection and Management of the High-Risk Patient with Elevated Blood Pressure. Vascular Health and Risk Management, 4, 289-296.

[2] Piccini, R.X. and Victora, C.G. (1994) Systemic Arterial Hypertension in a Urban Area of Southern Brazil: Prevalence and Risk Factors. Revista de Saúde Pública, 28, 261-267.

[3] Rywik, S.L., Davis, C.E., Pajak, A., Broda, G., Folsom, A.R., Kawalec, E. and Williams, O.D. (1998) Poland and US Collaborative Study on Cardiovascular Epidemiology Hypertension in the Community: Prevalence, Awareness, Treatment, and Control of Hypertension in the Pol-MONICA Project and the US Atherosclerosis Risk in Communities Study. Annals of Epidemiology, 8, 3-13. http://dx.doi.org/10.1016/S1047-2797(97)00177-4

[4] Col, M. and Ozyurda, F. (1992) Park Saglik Ocagi Bolgesinde 40 yas uzeri Nufusta Hipertansiyon Prevalansi. Ankara Tip Mecmuasi, 45, 247-262.

[5] Sadeghi, M., Roohafza, H.R. and Kelishadi, R. (2004) Blood Pressure and Associated Cardiovascular Risk Factors in Iran: Isfahan Healthy Heart Programme. Medical Journal of Malaysia, 59, 460-467.

[6] Satman, I., Yılmaz, T., Şengül, A., Salman, S., Salma, F., Uygur, S., Bastar, I. and Tutuncu, Y. (2002) PopulationBased Study of Diabetes and Risk Characteristics in Turkey: Results of the Turkish Diabetes Epidemiology Study 
(TURDEP). Diabetes Care, 25, 1551-1556. http://dx.doi.org/10.2337/diacare.25.9.1551

[7] Murphy, J.M., Laird, N.M., Monson, R.R., Sobol, A.M. and Leighton, A.H. (2000) A 40-Year Perspective on the Prevalence of Depression: The Stirling County Study. Archives of General Psychiatry, 57, 209-215. http://dx.doi.org/10.1001/archpsyc.57.3.209

[8] Bekaroğlu, M., Uluutku, N., Tanriöver, S. and Kirpinar, I. (1991) Depression in an Elderly Population in Turkey. Acta Psychiatrica Scandinavica, 84, 174-178. http://dx.doi.org/10.1111/j.1600-0447.1991.tb03124.x

[9] Frasure-Smith, N., Lesperance, F. and Talajic, M. (1995) The Impact of Negative Emotions on Prognosis Following Myocardial Infarction: Is It More than Depression? Health Psychology, 5, 388-398. http://dx.doi.org/10.1037/0278-6133.14.5.388

[10] Jonas, B.S., Franks, P. and Ingram, D.D. (1997) Are Symptoms of Anxiety and Depression Risk Factors for Hypertension? Longitudinal Evidence from the National Health and Nutrition Examination Survey I Epidemiologic Follow-Up Study. Archives of Family Medicine, 6, 43-49. http://dx.doi.org/10.1001/archfami.6.1.43

[11] Carroll, D., Phillips, A.C., Gale, C.R. and Batty, G.D. (2010) Generalized Anxiety and Major Depressive Disorders, Their Comorbidity and Hypertension in Middle-Aged Men. Psychosomatic Medicine, 72, 16-19. http://dx.doi.org/10.1097/PSY.0b013e3181c4fca1

[12] Beck, A.T., Ward, C.H., Mendelson, M., Mock, J. and Erbaugh, J. (1961) An Inventory for Measuring Depression. Archives of General Psychiatry, 4, 561-571. http://dx.doi.org/10.1001/archpsyc.1961.01710120031004

[13] Hisli, N. (1988) Beck Depresyon Envanterinin Gecerligi Uzerine bir Calisma. Journal of Psychology, 6, 118-122.

[14] Chobanian, A.V., Bakris, G.L., Black, H.R., Cushman, W.C., Green, L.A., Izzo Jr., J.L., Jones, D.W., Materson, B.J., Oparil, S., Wright Jr., J.T., Roccella, E.J., National Heart, Lung, and Blood Institute Joint National Committee on Prevention, Detection, Evaluation, and Treatment of High Blood Pressure, National High Blood Pressure Education Program Coordinating Committee (2003) The Seventh Report of the Joint National Committee on Prevention, Detection, Evaluation and Treatment of High Blood Pressure: The JNC 7 Report. JAMA, 289, 2560-2572. http://dx.doi.org/10.1001/jama.289.19.2560

[15] Kim, J.S., Jones, D.W., Kim, S.J. and Hong, Y.P. (1994) Hypertension in Korea: A National Survey. American Journal of Preventive Medicine, 10, 200-204.

[16] Bramlage, P., Pittrow. D., Wittchen, H.U., Kirch, W., Boehler, S., Lehnert, H., Hoefler, M., Unger, T. and Sharma, A.M. (2004) Hypertension in Overweight and Obese Primary Care Patients İs Highly Prevalent and Poorly Controlled. American Journal of Hypertension, 17, 904-910. http://dx.doi.org/10.1016/j.amjhyper.2004.05.017

[17] Abaci, A., Oguz, A., Kozan, O., Toprak, N., Senocak, H., Deger, N., Sahin, M., Sur, H., Fici, F. and Erol, C. (2006) Treatment and Control of Hypertension in Turkish Population: A Survey on High Blood Pressure in Primary Care (the TURKSAHA Study). Journal of Human Hypertension, 20, 355-361. http://dx.doi.org/10.1038/sj.jhh.1001995

[18] da Costa, J.S., Barcellos, F.C., Sclowitz, M.L., Sclowitz, I.K., Castanheira, M., Olinto, M.T., Menezes, A.M., Gigante, D.P., Macedo, S. and Fuchs, S.C. (2007) Hypertension Prevalence and Its Associated Risk Factors in Adults: A Population-Based Study in Pelotas. Arquivos Brasileiros de Cardiologia, 88, 59-65.

[19] Krause, R.M., Winston, M., Fletcher, B.J. and Grundy, S.M. (1998) Obesity. Impact on Cardiovascular Disease. Circulation, 98, 1472-1476. http://dx.doi.org/10.1161/01.CIR.98.14.1472

[20] Hall, J.E., Hildebrandt, D.A. and Kuo, J. (2001) Obesity Hypertension: Role of Leptin and Sympathetic Nervous System. American Journal of Hypertension, 14, 103-115. http://dx.doi.org/10.1016/S0895-7061(01)02077-5

[21] Hunt, S.C., Hopkins, P.N. and Lalouel, J.M. (2002) Hypertension. In: King, R.A., Rotter, J.I., Motulsky, A.G., Eds., The Genetic Basis of Common Diseases, 2nd Edition, Oxford University Press, New York, 127-154.

[22] El-Shafei, S.A., Bassili, A., Hassanien, N.M. and Mokhtar, M.M. (2002) Genetic Determinants of Essential Hypertension. The Journal of the Egyptian Public Health Association, 77, 231-246.

[23] Karl, T. and Herzog, H. (2007) Behavioral Profiling of NPY in Aggression and Neuropsychiatric Diseases. Peptides, 28, 326-333. http://dx.doi.org/10.1016/j.peptides.2006.07.027 
Scientific Research Publishing (SCIRP) is one of the largest Open Access journal publishers. It is currently publishing more than 200 open access, online, peer-reviewed journals covering a wide range of academic disciplines. SCIRP serves the worldwide academic communities and contributes to the progress and application of science with its publication.

Other selected journals from SCIRP are listed as below. Submit your manuscript to us via either submit@scirp.org or Online Submission Portal.
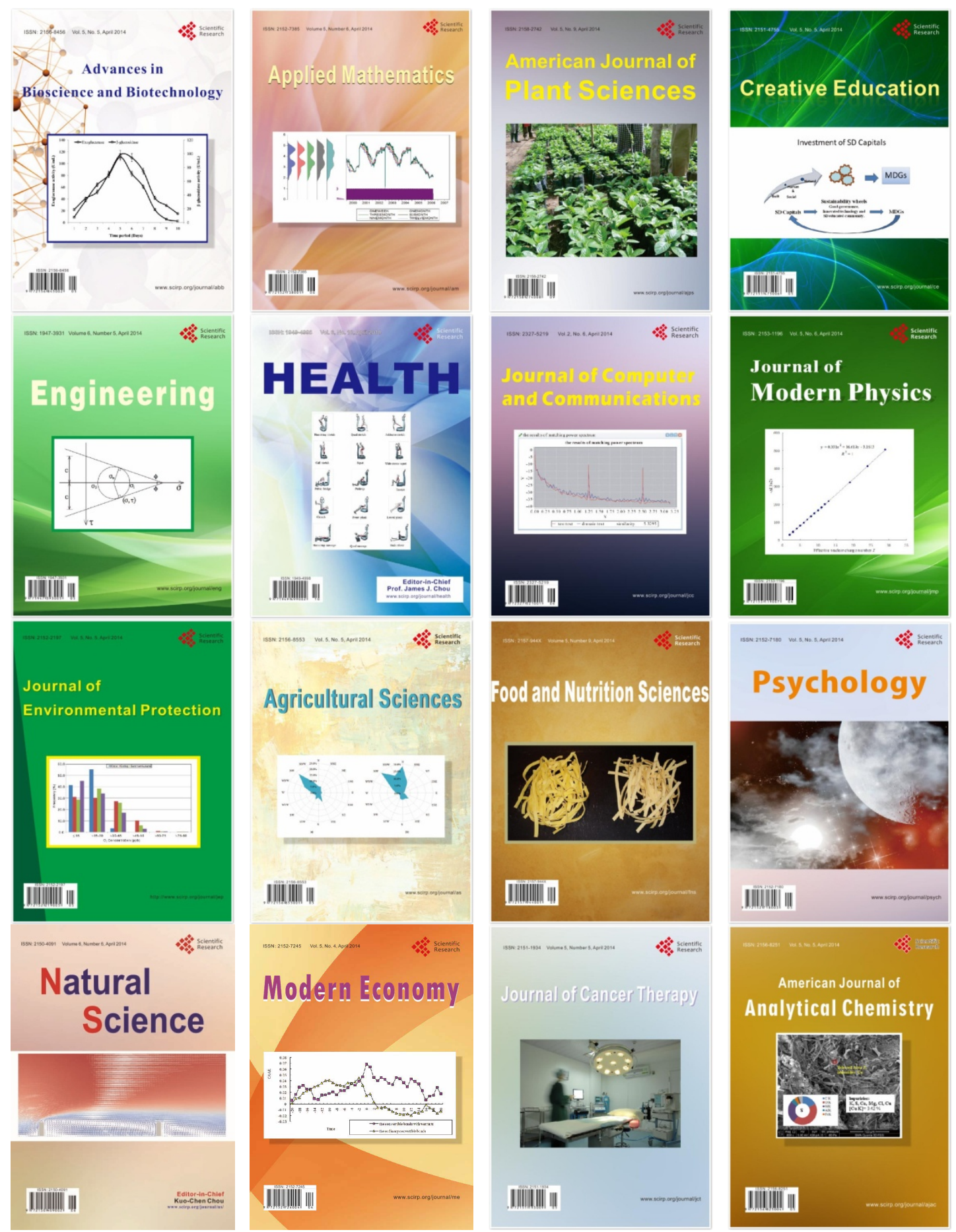